DOI: 10.20961/jpscr.v4i1.27292

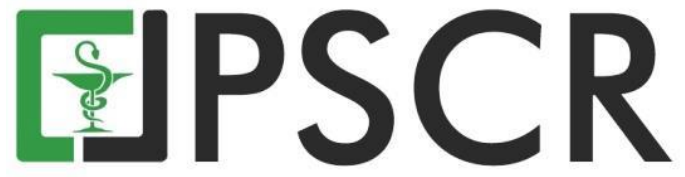

\title{
Aktivitas Hipoglikemik Diet Pakan Ekstrak Biji Labu Kuning (Cucurbita moschata Duch) Pada Mencit Diabetes Melitus Terpapar Streptozotocin
}

\author{
Suwanto* dan Rita Rahmawati \\ Program Studi Ilmu Keperawatan, Fakultas Ilmu Kesehatan, Universitas Gresik \\ *email korespondensi : suwantofatima@gmail.com
}

\begin{abstract}
Abstrak: Pangan berpengaruh terhadap kesehatan tubuh, sehingga pangan dapat mencegah dan mengobati penyakit seperti penyakit diabetes melitus. Pencegahan dan pengobatan diabetes melitus salah satunya dengan memanfaatkan biji labu kuning (Cucurbita moschata Duch). Kandungan biji labu kuning kaya akan protein, rendah lemak dan kalori. Protein biji labu kuning dapat dimanfaatkan sebagai diet hipoglikemik. Penelitian ini bertujuan untuk mengetahui aktivitas pemberian diet pakan ekstrak biji labu kuning terhadap peningkatan berat badan mencit dan untuk mengetahui aktivitas hipoglikemiknya pada mencit diabetes melitus terpapar streptozotocin. Metode penelitian menggunakan rancangan acak kelompok dengan desain penelitian post test only control group design. Mencit sebanyak 21 ekor dibagi menjadi 6 kelompok, kelompok I sebagai kontrol normal, kelompok II sebagai kontrol diabetes, kelompok III sebagai kontrol diabetes diberi metformin, kelompok IV-VI sebagai kelompok perlakuan diet pakan ekstrak biji labu kuning dengan konsentrasi 10\%, 20\%, dan 40\%. Pengamatan dilakukan terhadap pengukuran berat badan dan kadar glukosa darah. Data hasil penelitian dilakukan analisis statistik menggunakan ANOVA. Hasil penelitian menunjukkan bahwa pemberian diet pakan ekstrak biji labu kuning konsentrasi $10 \%$ berpengaruh terhadap peningkatan berat badan mencit sebanyak 0,25 gram serta lebih efektif menurunkan kadar glukosa darah sebanyak -29,25 $\mathrm{mg} / \mathrm{dl}$. Dari hasil penelitian dapat disimpulkan bahwa pemberian diet pakan ekstrak biji labu kuning berpengaruh terhadap peningkatan berat badan dan penurunan glukosa darah mencit diabet terpapar streptozotocin.
\end{abstract}

Kata kunci: Biji labu kuning; Streptozotocin; Hipoglikemik, Cucurbita moschata Duch

\begin{abstract}
Hypoglycemic Activity of Pumpkin Seed (Cucurbita moschata Duch) Extract Feed Diet in Diabetes Mellitus Mice Induced by Streptozotocin. Food affects the health of the body, therefore food can prevent and treat diseases such as diabetes mellitus. Prevention and treatment of diabetes mellitus by using pumpkin seed. Pumpkin seed rich of protein, low fat and calories. Pumpkin seed protein can be used as a hypoglycemic diet. The aim of this study was to determine the activity of pumpkin seed extract as feed diet to increase the body weight of mice and to determine the hypoglycemic activity in diabetes mellitus mice induced by streptozocin. The research used a randomized post-test only control group design. Twenty one mice were divided into 6 groups, group I as normal control, group II as diabetics control, group III as control of diabetes given with metformin, group IV-VI as a treatment group of pumpkin seed extract feed diet with 10\%, 20\%, and 40\%. Body weight and blood glucose were measured, observed, and analyzed using ANOVA. The results showed that the administration of $10 \%$ pumpkin seed extract as feed diet had an effect on increasing the body weight of mice by 0.25 grams and also more effective to decrease blood glucose by $-29.25 \mathrm{mg} / \mathrm{dl}$. This research showed
\end{abstract}


that the administration of pumpkin seed extract as feed diet has an effect on increasing body weight and decreasing blood glucose in diabetic mice induced by streptozotocin.

Keywords: Pumpkin seeds; Streptozotocin; Hypoglycemic, Cucurbita moschata Duch

\section{Pendahuluan}

Sumber bahan pangan yang dimanfaatkan untuk memenuhi kebutuhan hidup sangat prioritas pada setiap orang, karena pangan merupakan sumber energi untuk kelangsungan hidup. Sumber bahan pangan yang dimanfaatkan sangat berpengaruh terhadap nilai kesehatan. Oleh karena itu dalam memanfaatkan sumber bahan pangan harus melihat kandungan nutrisinya. Sumber bahan pangan dapat mencegah dan mengobati penyakit seperti halnya penyakit diabetes melitus. Penyakit tersebut merupakan gangguan sindrom pada metabolisme karbohidrat, lemak, protein yang disebabkan oleh kekurangan hormon insulin atau penurunan sensitifitas terhadap jaringan insulin (Sharma et al, 2013; Kawatu dkk, 2013).

Penderita diabetes melitus mempunyai resiko 2-4 kali terkena aterosklerosis dan komplikasinya dibandingkan bukan penderita diabetes melitus (Hartoyo dkk, 2011). Beberapa kondisi penderita diabetes melitus yang dapat menyebabkan terjadinya aterosklerosis antara lain hiperglikemia, dislipidemia, tingginya stres oksidatif, dan produk glikasi (Renard et al, 2004). Diabetes melitus merupakan salah satu masalah kesehatan masyarakat di dunia, termasuk Indonesia. Penderita diabetes melitus akan menjadi masalah kesehatan nasional sehingga penanganan dan atau pencegahannya perlu mendapat perhatian serius dari semua pihak (Wisaniyasa dkk, 2001; Meral et al, 2004).

Terapi diabetes melitus biasanya dilakukan menggunakan obat modern yang dibuat dari bahan sintesis yang tujuannya untuk mencegah dan mengobati penyakit tersebut. Pengobatan dengan menggunakan obat modern yang dibuat dari bahan sintesis sangat berbahaya, karena pengobatan tersebut menimbulkan dampak negatif bagi kesehatan (Manolong, 2010). Pada umumnya masyarakat sering memanfaatkan obat modern yang dibuat dari bahan sintesis sebagai pengobatan dibandingkan memanfaatkan pengobatan tradisional yaitu dengan memanfaatkan potensi kekayaan alam seperti tanaman herbal.

Tanaman herbal mengandung senyawa-senyawa yang mempunyai khasiat pengobatan, yang dikenal sebagai senyawa fitokimia, yaitu kelompok senyawa alami yang bisa dimanfaatkan untuk menjaga kesehatan dan mengobati beberapa penyakit (Mahanom et al, 1999; Hernani dan Nurdjanah, 2009; Edeoga et al, 2005). Adapun pemanfaatan tanaman herbal tidak memiliki efek samping yang berbahaya bagi kesehatan karena bisa dicerna oleh tubuh sehingga aman bagi kesehatan (Setiawan 2010; Togubua dkk, 2013). Tanaman herbal memiliki senyawa fitokimia yang memberikan efek farmakologis adalah kelompok senyawa metabolit sekunder, antara lain 
golongan minyak atsiri, flavonoid, alkaloid, steroid, tripenoid, tanin, alkaloid, dan karbohidrat (Hernani dan Nurdjanah, 2009; Edeoga et al, 2005; Njoku \& Obi, 2009).

Pencegahan dan pengobatan penyakit diabetes melitus dapat memanfaatkan tanaman herbal yaitu labu kuning (Cucurbita moschata Duch). Tanaman labu kuning dapat dimanfaatkan sebagai pengobatan tradisional di banyak beberapa negara seperti China, Argentina, India, Mexiko, Brazil, dan Korea (Stevenson et al, 2007). Telah dilaporkan bahwa tanaman labu kuning mempunyai kandungan senyawa kimia seperti protein, lemak, mineral, petida, polisakarida, sterol, asam para aminobenzoic, vitamin A, vitamin $\mathrm{C}$, serat, air, oleat, linoleat $( \pm 30 \%)$, asam palmitat $( \pm 15 \%)$ dan phytosterol. (Suwanto, 2015; Yadav et al, 2009; Elemo et al, 2002 cit Bello et al, 2008; Elinge et al, 2012; Kim et al, 2012). Adapun kandungan dari labu kuning dapat menurunkan kadar glukosa darah pada penyakit diabetes melitus (Jin et al, 2013; Mahmoodpoor et al, 2018).

Penelitian ini menggunakan biji labu kuning. Kandungan protein pada biji labu kuning sangat tinggi yaitu 29.33 - 35.88\% (Badifu \& Ogunsua, 1991; Achu et al, 2005; Teugwa et al, 2013). Biji labu kuning rendah lemak dan rendah kalori (Stevenson et al, 2007). Protein pada biji labu kuning dapat dimanfaatkan sebagai diet makanan yang bersifat hipoglikemik. Makanan tersebut antara lain berupa makanan dengan kadar serat tinggi atau makanan berbasis protein (Wahyuni, 2015). Diet makanan dapat memperbaiki kadar glukosa darah dan mencegah serta menghambat terjadinya komplikasi. Penelitian sebelumnya yang dilakukan oleh Sharma et al, (2013) menunjukkan hasil ekstrak biji labu kuning dapat menurunkan glukosa darah dan kolesterol, sedangkan pada penelitian ini yang membedakan dari penelitian tersebut adalah pembuatan pakan ekstrak biji labu kuning dengan cara menggantikan kasein pada pakan standar dengan ekstrak biji labu kuning. Adapun tujuan dari penelitian ini untuk mengetahui aktivitas diet pakan ekstrak biji labu kuning terhadap peningkatan berat badan mencit dan untuk mengetahui aktivitas hipoglikemiknya pada mencit diabetes melitus terpapar streptozotocin. Berdasarkan latar belakang, maka perlu dilakukan penelitian tentang aktivitas hipoglikemik diet pakan ekstrak biji labu kuning (Cucurbita moschata Duch) pada mencit diabetes terpapar streptozotocin.

\section{Bahan dan Metode}

\subsection{Alat}

Alat penumbuk biji, mesin pelet (Meat mincher), oven, (Memmet), baki, ayakan mesh, timbangan digital (Ohaus), alat pengambilan spesimen darah dan analisis gula darah (Accu check), seperangkat alat untuk pemeliharaan tikus, gunting, spuit injeksi (One Med). 


\subsection{Bahan}

Biji labu kuning diperoleh dari petani di Kabupaten Lamongan Jawa Timur, pakan ternak ayam M594 (Charoen Pokphand), hewan yang digunakan adalah mencit strain BALB/C berat berkisar 30-40 gram umur 3-4 bulan diperoleh dari laboratorium hewan coba FST Unair Surabaya, akuades, metformin (Hexpharm Jaya), buffer citrat pH 4,5, Carboxymethylcellulosa (Diasys), minyak babi diperoleh dari pasar Pabean Surabaya, streptozotocin (Sigma Aldrich), alkohol 70\% (One Med).

\subsection{Pembutan pakan ekstrak biji labu kuning}

Pembuatan pakan ekstrak biji labu kuning dilakukan dengan cara mengurangi dan menggantikan kasein pada pakan standar dengan ekstrak biji labu kuning. Telah dianalisa menggunakan uji analisis proksimat bahwa kandungan biji labu kuning adalah kadar protein lebih banyak yaitu 30,2768 \%; kadar lemak 6,6791\%; kadar serat 16,8780\%, dan kadar abu $5,0309 \%$. Adapun pembuatan pakan ekstrak biji labu kuning dengan cara mencampurkan tepung biji labu kuning dengan tepung pakan standar kemudian diberi air secukupnya. Pencampuran tepung labu kuning dengan tepung pakan standar dilakukan sampai terbentuk adonan yang homogen. Adonan selanjutnya dimasukan ke dalam mesin pencetak hingga diperoleh pakan berbentuk slinder panjang. Pakan yang telah dicetak selanjutnya dikeringkan dalam oven selama 24 jam pada suhu $60^{\circ} \mathrm{C}$. Pembuatan pakan ekstrak biji labu kuning dapat dibedakan menjadi 3 macam konsentrasi yaitu konsentrasi I sebanyak 10\% dengan komposisi pencampuran tepung biji labu kuning sebanyak 50 gram ditambah dengan 450 gram pakan tepung standar dan diberi air secukupnya; konsentrasi II sebanyak 20\% dengan komposisi pencampuran tepung biji labu kuning sebanyak 100 gram ditambah dengan 400 gram pakan tepung standar dan diberi air secukupnya; dan konsentrasi III sebanyak $40 \%$ dengan komposisi pencampuran tepung biji labu kuning sebanyak 200 gram ditambah dengan 300 gram pakan tepung standar dan diberi air secukupnya.

\subsection{Pengujian hewan coba (bioassay)}

Pengujian hewan coba (bioassay) menggunakan mencit sebanyak 21 ekor dibagi 6 kelompok, kelompok I sebagai kontrol normal, kelompok II sebagai kontrol diabetes, kelompok III sebagai kontrol diabetes diberi metformin, kelompok IV-VI sebagai kelompok perlakuan diet pakan ekstrak biji labu kuning dengan konsentrasi 10\%, 20\%, dan 40\%.

Sebelum dilakukan pemaparan streptozotocin pada mencit, mencit yang baru dipesan di aklimatisasi dan diberi minyak babi sebanyak 0,3 ml selama 2 minggu. Pemberian minyak babi ini bertujuan untuk merangsang terjadinya hiperglikemik. Selama aklimatisasi mencit tetap diberikan makan minum yang cukup. Setiap 2 hari dalam satu minggu, sekam selalu diganti agar 
kandang dalam keadaan bersih. Setelah dilakukan aklimatisasi dan pemberian minyak babi, maka mencit dipaparkan atau diinduksi menggunakan streptozotocin sebanyak 0,15 ml/30 kg BB secara intraperitoneal yang bertujuan agar mencit dalam keadaan hiperglikemik. Injeksi streptozotocin dilakukan selama 5 hari berturut-turut. Adapun prosedur induksi mengacu pada penelitian Novelli et al, (2010) dan Husen dan Winarni (2013).

Sebelum dilakukan perlakuan diet pakan ekstrak biji labu kuning, mencit ditimbang untuk mengetahui berat badan mencit sebelum dan sesudah diberi perlakuan. Setelah dilakukan penimbangan berat badan mencit maka dilakukan pengukuran glukosa darah mencit. Pengukuran glukosa darah dilakukan sebelum dan sudah diberi perlakuan diet pakan ekstrak biji labu kuning. Pemberian diet pakan ekstrak biji labu kuning merupakan perlakuan untuk menurunkan glukosa darah mencit diabet yang disebabkan oleh induksi streptozotocin selama 5 hari berturut-turut. Pemberian diet pakan ekstrak biji labu kuning dilakukan selama 14 hari.

Kadar glukosa darah selanjutnya diukur pada akhir perlakuan. Adapun tahapan pengukuran glukosa darah adalah ekor mencit dibersihkan terlebih dahulu dengan alkohol $70 \%$ dan dikeringkan dengan kapas. Selanjutnya ujung ekor digunting sedikit dengan gunting yang tajam. Tetesan darah yang diperoleh lalu diteteskan di atas strip glukometer yang telah dikalibrasi sebelumnya. Kadar glukosa darah akan terukur pada alat setelah 5 detik dan dinyatakan dalam satuan mg/dl. Mencit dianggap diabetes jika glukosa darah puasa $\geq 200 \mathrm{mg} / \mathrm{dl}$ (Patel et al, 2015).

\subsection{Teknik pengumpulan dan analisis data}

Data hasil penelitian dilakukan analisis statistik. Untuk mengetahui data terdistribusi normal maka dilakukan uji Kolmogorov Smirnov, kemudian dilanjutkan uji homogenitas menggunakan analisis varian (ANOVA) dan bila terdapat perbedaan yang nyata antar kelompok maka dilakukan uji Post Hoc Duncan dengan $\mathrm{p}<0,05$.

\section{Hasil dan Pembahasan}

\subsection{Pengaruh diet pakan ekstrak biji labu kuning terhadap perubahan berat badan mencit diabetes melitus}

Pengaruh pemberian diet pakan ekstrak biji labu kuning pada konsentrasi 10\%, 20\% dan 40\% selama 14 hari terhadap perubahan berat badan mencit diabetes melitus dapat dilihat pada gambar 1. Adapun data perubahan berat badan mencit tersaji pada tabel 1. Perubahan berat badan merupakan selisih antara berat badan pada akhir perlakuan dengan berat badan pada awal perlakuan.

Berdasarkan tabel 1 diketahui bahwa terjadi perubahan berat badan mencit diabetes, perubahan berat badan dapat mengalami peningkatan dan penurunan. Adapun peningkatan berat badan mencit diabetes pada kelompok kontrol normal sebanyak 0,87 gram, kelompok metformin 
sebanyak 0,55 gram, dan kelompok perlakuan P1 sebanyak 0,25 gram. Sedangkan penurunan berat badan terjadi pada kelompok kontrol diabet sebanyak -0,95 gram, kelompok perlakuan P2 sebanyak -0,75 gram, dan kelompok perlakuan P3 sebanyak -3,93 gram.

Tabel 1. Perubahan badan mencit diabetes melitus terhadap pemberian diet pakan ekstrak biji labu kuning pada konsentrasi 10\%, 20\% dan 40\% selam 14 hari.

\begin{tabular}{lcccc}
\hline \multicolumn{1}{c}{ Kelompok } & $\begin{array}{c}\text { Jumlah } \\
\text { sampel }\end{array}$ & $\begin{array}{c}\text { Mean BB (gram) } \\
\text { awal perlakuan }\end{array}$ & $\begin{array}{c}\text { Mean BB (gram) } \\
\text { akhir perlakuan }\end{array}$ & $\begin{array}{c}\text { Perubahan } \\
\text { BB }\end{array}$ \\
\hline Kontrol Normal & 4 & 34,7 & 35,57 & 0,87 \\
Kontrol Diabet & 4 & 28,4 & 27,45 & $-0,95$ \\
Kontrol & 4 & 32,57 & 33,12 & 0,55 \\
Metformin & & & & \\
Perlakuan P1 & 4 & 27,32 & 27,57 & 0,25 \\
Perlakuan P2 & 4 & 36 & 35,25 & $-0,75$ \\
Perlakuan P3 & 4 & 35,2 & 31,27 & $-3,93$ \\
Total & 24 & $\mathbf{1 9 4 , 1 9}$ & $\mathbf{1 9 0 , 2 3}$ & $\mathbf{- 3 , 9 6}$ \\
& \multicolumn{2}{c}{ Uji Anova = 0,33 } \\
\hline
\end{tabular}

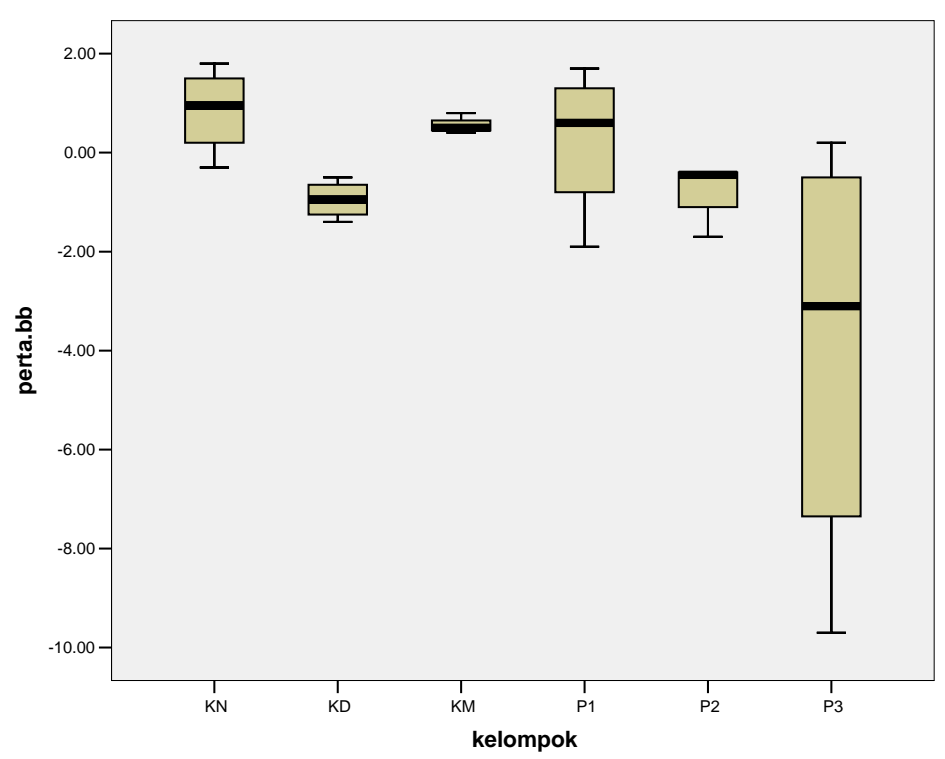

Gambar 1. Pengaruh ekstrak protein biji labu kuning terhadap perubahan berat badan mencit mencit diabetes melitus. KN (Kelompok kontrol normal); KD (Kelompok kontrol diabetes); KM (Kelompok kontrol diabet diberi metformin HCL 100 mg/kg BB); Kelompok perlakuan P1 (10\%); Kelompok perlakuan P2 (20\%); Kelompok perlakuan P3 (40\%).

Seperti terlihat pada gambar 1 dapat diketahui bahwa kondisi hiperglikemik dapat menyebabkan terjadinya penurunan berat badan pada kelompok diabetik (KD) sebanyak -0,95 gram. Adanya penurunan berat badan mencit diabetes disebabkan oleh adanya paparan streptozotocin pada mencit. Menurut Carvalho et al, (2003) agen diabetogenik seperti 
streptozotocin berpengaruh terhadap berat badan. Penurunan berat badan terjadi dikarenakan kehilangan massa tubuh (Szkudelzki, 2001; Lenzen, 2008). Dengan berkurangnya insulin, tubuh akan merespon untuk menghasilkan energi dengan melakukan glikogenolisis, glukoneogenesis, dan lipolisis. Penghancuran protein dan lemak tubuh tersebut mengakibatkan penurunan berat badan pada mencit diabetes. Sedangkan pada kelompok perlakuan P2 (20\%), dan kelompok perlakuan P3 (40\%) juga mengalami penurunan berat badan antara lain perlakuan P2 sebanyak 0,75 gram dan perlakuan P3 sebanyak -3,92 gram. Penurunan berat badan pada kelompok perlakuan tersebut disebabkan oleh tingginya dosis atau antioksidan pada ekstrak biji labu kuning yang diberikan pada mencit, sehingga jumlah antioksidan yang ada pada ekstrak biji labu kuning menjadi sejenis muatan reaktif yang memiliki fungsi seperti radikal bebas, maka pemulihan sel-sel pankreas yang rusak diakibatkan oleh streptozotocin menjadi lebih lambat. Konsentrasi yang baik digunakan dalam meningkatkan berat badan mencit pada kelompok perlakuan P1 (10\%) lebih efektif dibandingkan dengan kelompok diabetes, kelompok perlakuan P2 (20\%), dan kelompok perlakuan P3 (40\%). Terjadinya peningkatan berat badan sebanyak 0,25 gram pada kelompok perlakuan P1 menunjukkan terjadinya perbaikan sel-sel beta pankreas yang berdampak pada peningkatan hormon insulin, sehingga glukosa mampu diserap oleh sel-sel otot dan sel hepar, sehingga terjadi perubahan berat badan pada hewan coba. Berdasarkan adanya peningkatan berat badan sebanyak 0,25 gram pada kelompok perlakuan P1 (10\%) menunjukkan bahwa ekstrak biji labu kuning selain mampu menurunkan kadar gula darah akibat kondisi diabetes, juga mampu memperbaiki jaringan pankreas terutama perbaikan sel-sel beta pankreas.

Terdapat peningkatkan berat badan mencit diabet sebanyak 0,55 gram pada kelompok metformin. Metformin merupakan obat sintesis yang digunakan sebagai terapi dibetes mellitus. Telah diketahui bahwa metformin memiliki mekanisme spesifik dalam menurunkan glukosa darah. Mekanisme tersebut meliputi stimulasi glikolisis langsung pada jaringan perifer dengan peningkatan pengeluaran glukosa dari darah, pengurangan kadar glukagon dalam plasma dan meningkatkan pengikatan insulin pada reseptor insulin. Mekanisme kerja metformin dalam menurunkan kadar glukosa darah tidak tergantung atas adanya sel beta pankreas yang berfungsi (Prameswari dan Widjanarko, 2014).

Dari hasil uji korelasi Person dapat diketahui bahwa ada hubungan negatif yang signifikan antara peningkatan rerata kadar glukosa darah dengan rerata penambahan berat badan mencit. Semakin besar rerata kadar glukosa darah yang terukur semakin menurun rerata berat badan mencit yang tertimbang. Hal tersebut ditunjukkan dengan nilai korelasinya sebesar $-0,48$, dalam taraf signifikansi $\alpha=0,01$. Terjadinya penurunan berat badan merupakan salah satu akibat kondisi hiperglikemia (American Diabetes Association, 2010). Kondisi hiperglikemia kronik 
menyebabkan berbagai komplikasi diabetes melitus, antara lain neuropati, retinopati, nefropati dan kerusakan pembuluh darah kecil mikro maupun makro (Evans et al, 2003).

\subsection{Pengaruh diet pakan ekstrak biji labu kuning terhadap perubahan glukosa darah mencit diabetes melitus}

Pengaruh pemberian diet pakan ekstrak protein biji labu kuning dengan konsentrasi P1 (10\%), P2 (20\%) dan P3 (40\%), selama 14 hari terhadap kadar glukosa darah mencit diabetes melitus dapat dilihat pada gambar 2. Sedangkan data perubahan kadar glukosa darah mencit diabetes melitus tersaji pada tabel 2. Pengukuran kadar glukosa darah dilakukan sebelum perlakuan dan akhir perlakuan.

Tabel 2. Perubahan kadar glukosa darah mencit diabet melitus terhadap pemberian diet pakan ekstrak protein biji labu kuning selam 14 hari

\begin{tabular}{lcccc}
\hline Kelompok & $\begin{array}{c}\text { Jumlah } \\
\text { sampel }\end{array}$ & $\begin{array}{c}\text { Mean kadar } \\
\text { glukosa darah } \\
\text { (mg/dl) awal } \\
\text { perlakuan }\end{array}$ & $\begin{array}{c}\text { Mean kadar } \\
\text { glukosa darah } \\
(\mathbf{m g} / \mathbf{d l}) \text { akhir } \\
\text { perlakuan }\end{array}$ & $\begin{array}{c}\text { Perubahan } \\
\text { Kadar glukosa } \\
\text { darah }\end{array}$ \\
\hline Kontrol Normal & 4 & 123,75 & 125,25 & 1,5 \\
Kontrol Diabet & 4 & 244,75 & 295,25 & 50,5 \\
Kontrol & 4 & 184 & 123 & -61 \\
Metformin & & & & \\
Perlakuan P1 & 4 & 211 & 181,75 & $-29,25$ \\
Perlakuan P2 & 4 & 172,75 & 178 & 5,25 \\
Perlakuan P3 & 4 & 215,5 & 248,5 & 33 \\
Total & 24 & $\mathbf{1 1 5 1 , 7 5}$ & $\mathbf{1 1 5 1 , 7 5}$ & $\mathbf{0}$ \\
& & Uji Anova $=\mathbf{0 , 1 0 8}$ & & \\
\hline
\end{tabular}

Berdasarkan tabel 2 diketahui bahwa terjadi perubahan glukosa darah mencit diabetes. Perubahan glukosa darah dapat mengalami peningkatan dan penurunan. Adapun peningkatan glukosa darah mencit diabetes pada kelompok kontrol normal sebanyak 1,5 mg/dl, kelompok kontrol diabetes sebanyak 50,5 mg/dl, kelompok perlakuan P2 sebanyak 5,25 mg/dl, dan kelompok perlakuan P3 sebanyak $33 \mathrm{mg} / \mathrm{dl}$. Sedangkan penurunan glukosa darah mencit diabetes pada kelompok kontrol metformin sebanyak -61 mg/dl dan kelompok perlakuan P1 sebanyak $-29,25 \mathrm{mg} / \mathrm{dl}$.

Dari gambar 2 dapat diketahui bahwa pemberian diet pakan ekstrak biji labu kuning pada kelompok perlakuan P1, P2 dan P3 dapat menurunkan glukosa darah dibandingkan dengan kelompok mencit diabetes. Kelenjar pankreas pada kelompok mencit diabet terpapar streptozotocin dapat rusak, yang ditandai dengan mengecilnya pulau langerhans dan rapuhnya jaringan pankreas. Hal ini menyebabkan sekresi insulin ke dalam darah mengalami penurunan, 
yang berakibat pada meningkatnya kadar glukosa darah pada kelompok diabetes. Penurunan glukosa darah pada kelompok tersebut antara lain P1 (-29,25 mg/dl); P2 (5,25 mg/dl); dan P3 (33,00 mg/dl). Kelompok perlakuan yang lebih efektif dalam menurunkan glukosa darah mencit diabetes adalah kelompok perlakuan P1 konsentrasi 10\% dibandingkan dengan kelompok perlakuan P2 konsentrasi 20\% dan kelompok perlakuan P3 konsentrasi 40\%. Kelompok perlakuan P2 dengan konsentrasi 20\% dan kelompok perlakuan P3 dengan konsentrasi 40\% memiliki kandungan antioksidan yang sangat tinggi. Tingginya kandungan antioksidan pada ekstrak biji labu kuning menjadi sejenis muatan reaktif yang memiliki fungsi seperti radikal bebas.

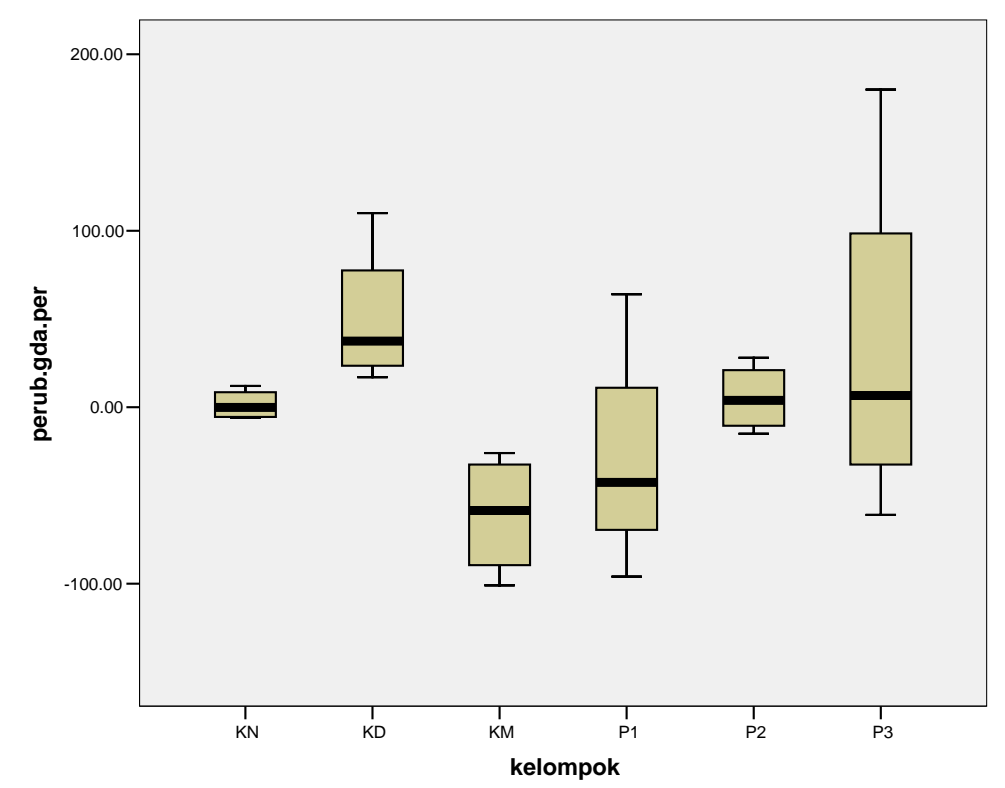

Gambar 2. Pengaruh diet pakan ekstrak biji labu kuning terhadap perubahan glukosa darah mencit diabetes melitus. KN (Kelompok kontrol normal); KD (Kelompok kontrol diabetes); KM (Kelompok kontrol diabetes diberi metformin HCL 100 mg/kg BB); Kelompok perlakuan P1 (10\%); Kelompok perlakuan P2 (20\%); Kelompok perlakuan P3 (40 \%).

Penurunan glukosa darah pada mencit diabetes disebabkan oleh kandungan ekstrak biji labu kuning seperti tinggi protein, rendah terhadap lemak dan kalori sehingga mampu merangsang sintesis hormon insulin pada sel beta pankreas. Terjadinya sintesis insulin diduga sel beta pankreas telah terjadi perbaikan, karena protein yang terdapat pada biji labu kuning berpotensi sebagai insulinotrophic agent. Hal tersebut ditunjukkan dengan adanya efek sinergis dengan glukosa terhadap peningkatan sekresi insulin pada sel beta pankreas (Badifu \& Ogunsua, 1991; Achu et al, 2005; Teugwa et al, 2013; Stevenson et al, 2007; Lee and Park, 2000). Hasil penelitian oleh Sharma et al, 2013 menunjukkan bahwa penggunaan ekstrak biji labu kuning dapat menurunkan glukosa darah dan kolesterol pada mencit diabet 
Protein pada biji labu kuning dapat dimanfaatkan sebagai diet makanan yang bersifat hipoglikemik, makanan tersebut antara lain berupa makanan dengan kadar serat tinggi atau makanan berbasis protein (Wahyuni, 2015). Diet makanan dapat memperbaiki kadar glukosa darah dan mencegah serta menghambat terjadinya komplikasi. Sedangkan kelompok metformin juga dapat menurunkan glukosa darah mencit diabetes sebanyak -61,00 mg/dl. Obat metformin merupakan obat sintesis yang bisanya digunakan bagi penderita diabetes, dan obat tersebut tidak boleh digunakan secara terus menurus karena dapat berdampak pada organ tubuh lainnya. Obat sintesis seperti metformin sulit untuk diabsorbsi dalam tubuh. Jadi obat herbal dari tanaman dalam mengendalikan atau pengobatan diabetes melitus lebih baik seperti halnya pemanfaatan biji labu kuning yang dapat digunakan sebagai penurun glukosa darah. Efek pemberian obat herbal yang diberikan dalam pengobatan diabetes melitus lebih sedikit dampaknya dibanding obat sintesis (Sari, 2006; Bustanussalam, 2016).

Hasil uji Kolmogorov Smirnov menunjukkan bahwa data terdistribusi normal $(\mathrm{P}>0,05)$. Kemudian dilanjutkan dengan uji homogenitas, data menunjukkan homogen $(\mathrm{P}>0,05)$. Karena data normal dan homogen selanjutnya dilakukan uji ANOVA satu arah. Hasil uji ANOVA satu arah menunjukkan adanya beda signifikan diantara kelompok perlakuan, dengan $\mathrm{p}<0,05$ pada $\alpha$ 0,05 . Selanjutnya perbedaan yang bermakna dari rerata masing-masing perlakuan, dapat diketahui setelah dilakukan uji Post Hoc Duncan pada rerata perubahan glukosa darah mencit. Hasil uji Post Hoc Duncan menunjukkan bahwa kelompok kontrol normal berbeda signifikan apabila dibandingkan dengan kelompok kontrol diabetes, tetapi tidak berbeda signifikan dengan kelompok diabetes diberikan metformin dan kelompok perlakuan P1,P2 dan P3.

Berdasarkan hasil penelitian yang dilakukan menunjukkan bahwa pemanfaatan biji labu kuning dapat digunakan sebagai penurun glukosa darah pada penyakit diabetes melitus, selain itu biji labu kuning aman untuk dikonsumsi dan mudah diperoleh.

\section{Kesimpulan}

Pemberian diet pakan ekstrak biji labu kuning pada konsentrasi $10 \%$ berpengaruh terhadap peningkatan berat badan sebanyak 0,25 gram dan lebih efektif terhadap penurunan kadar glukosa darah sebanyak -29, $25 \mathrm{mg} / \mathrm{dl}$ pada mencit diabetes terpapar streptozotocin.

\section{Ucapan Terima Kasih}

Terimakasih, kami sampaikan kepada Direktorat Riset dan Pengabdian Masyarakat, Direktorat Jenderal Penguatan Riset dan Pengembangan Kementerian Riset, Teknologi, dan 
Pendidikan Tinggi sesuai dengan Kontrak Penelitian Tahun Anggaran 2018 yang telah mendanai penelitian ini melalui Hibah Penelitian Dosen Pemula Tahun 2018.

\section{Daftar Pustaka}

Achu, B.M., Fokou, E., Tchiégang, C., Fotso, M., and Mbiapo, T.F. (2005). Nutritive value of some Cucurbitaceae oilseeds from different regions in Cameroon. Afr J Biotech, 4 (11) : 1329-1334.

American Diabetes Association. (2010). Diagnosis and Classification of Diabetes Mellitus. Diabetes Care, 33(1): 62-69.

Badifu, G.I., and Ogunsua, A.O. (1991). Chemical composition of kernels from some species of Cucurbitaceae grown in Nigeria. Plant Foods Hum Nutr, 41 (1) : 35-44.

Bustanussalam. (2016). Pemanfaataan obat tradisional (herbal) sebagai obat alternatif. Bio Trends.7(1):20-25.

http://terbitan.biotek.lipi.go.id/index.php/biotrends/article/viewFile/155/152 $\quad\left(\begin{array}{ll}16 & \text { Juli }\end{array}\right.$ 2018).

Carvalho, E.N., Carvalho, N.A.S. and Ferreira, L.M. (2003). Experimental model of induction of diabetes mellitus in rats. Acta Cirurgica Brasileira, 18(1): 1-8.

Edeoga, H.O., Okwu, D. E. and Mbaebie, B.O. (2005). Phytochemical constituents of some Nigerian medicinal plants. African Journal of Biotechnology, 4 (7) : 685-688.

Elemo, B.O. et al, 2002 cit Bello, M.O., Falade, O.S., Adewusi, S.R.A., Olawore, N.O. (2008). Studies on the chemical compositions and anti nutrients of some lesser known Nigeria fruits. African Journal of Biotechnology, 7(21) : 3972-3979.

Elinge, C.M., Muhammad, A., Atiku, F.A., Itodo, A.U., Peni, I. J., Sanni, O.M. and Mbongo, A.N. (2012). Proximate, Mineral and Anti-nutrient Composition of Pumpkin (Cucurbitapepo L) Seeds Extract. International Journal of Plant Research, 2(5) : 146-150.

Evans, J.L., Goldfine, I.D., Maddux, B.A. and Grodsky, G.M. (2003). Are oxidative stressactivated signaling pathways mediators of insulin resistance and beta-cell dysfunction? Diabetes, 52(1): 1-8.

Hartoyo, A., Muchtadi, D., Astawan, M., Dahrulsyah dan Winarto, A. (2011). Pengaruh Ekstrak Protein Kacang Komak (Lablab purpureus (L.) Sweet) Pada Glukosa Dan Profil Lipida Serum Tikus Diabetes. J.Teknol dan Industri Pangan, XXII (1) : 58-63.

Hernani dan Nurdjanah, R. (2009). Aspek Pengeringan Dalam Mempertahankan Kandungan Metabolit Sekunder Pada Tanaman Obat. Perkembangan Teknologi TRO, 21 (2) : 33-39.

Husen, A.S. dan Winarni, D. (2015). Uji Aktivitas Ekstrak Kulit Buah Manggis (Garcinia mangostana, L) Untuk Menurunkan Kolesterol Darah Puasa dan Aktivitas PeroksidasI Lipid Pada Mencit Diabetes Mellitus Tipe 2. Laporan Akhir Penelitian Unggulan Perguruan Tinggi, Universitas Airlangga. Surabaya.

Jin, H., Zhang, Y.J., Jiang, J.X., Zhu, L.Y., Chen, P., Li, J. and Yao, H.Y. (2013). Studies on the extraction of pumpkin components and their biological effects on blood glucose of diabetic mice. Journal of Food and Drug Analysis, 21(1): 184-189.

Kawatu C, W. Bodhi dan J. Mongi. 2013. Uji Efek Ekstrak Etanol Daun Kucing-Kucingan (Acalypha indica L.) terhadap Kadar glukosa darah Tikus Putih Jantan Galur Wistar (Rattus novergicus). Pharmacon Jurnal Ilmiah Farmasi. 2 (1) : 81-85. 
Kim, M.Y., Kim, E.J., Kim, Y.N., Choi, C. and Lee, B.H. (2012). Comparison of the chemical compositions and nutritive values of various pumpkin (Cucurbitaceae) species and parts. Nutrition Research and Practice, 2012 6(1) : 21-27.

Lenzen, S. (2008). The mechanisms of alloxan- and streptozotocin-induced diabetes. Diabetologia, 51(2): 216-226.

Lee, S.H. and Park, I.S. (2000). Effects of soybean diet on the $\beta$ cells in the streptozotocin treated rats for induction of diabetes. Diabetes Research and Clinical Practice, 47(1): 1-13.

Meral, I., Donmez, N., Baydas, B., Belge, F. and Kanter, M. (2004). Effect of Nigella sativa L. on herat rate and some haematological value alloxan induced diabetic rabbits. Scand. $J$. Lab. Anim. Sci, 31 (1) : 49-53.

Mahmoodpor, A., Medghalchi, M., Nazemiyeh, H., Asgharian, P., Shadvar, K. and Hamishehkar, H. (2018). Effect of Cucurbita Maxima on Control of Blood Glucose in Diabetic Critically Ill Patients. Adv Pharm Bull, 8(2): 347-351.

Manolong, V.V. (2010). Penggunaan Albumin Untuk Penurunan Kadar Tanin Dan Peningkatan Kualitas Serbuk Minuman Instan Biji Petai Cina (Leucaena leucocephala Lmk. de Wit). Skripsi, Fakultas Teknobiologi. Universitas Atma Jaya. Yogyakarta.

Njoku, V.O. and Obi, C. (2009). Phytochemical constituents of some selected medicinal plants. African Journal of Pure and Applied Chemistry, 3 (11) : 228-233.

Novelli et al. (2010). Persistent correction of hyperglycemia in streptozotocin-nicotinamideinduced diabetic mice by a non-conventional radical scavenger. Naunyn Schmiedebergs Arch Pharmacol, 382(2): 127-137.

Patel, B.J., Dave, B., Dave, D., Karmakar, P., Shah, M. and Sarvaiya, B. (2015). Comparison and Correlation of Glucose Levels in Serum and Saliva of Both Diabetic and Non-diabetic Patients. J Int Oral Health, 7(8): 70-76.

Prameswari, O.M. dan Widijanarko, S.B. (2014). Uji efek ekstrak air daun pandan wangi terhadap penurunan kadar glukosa darah dan histopatologi tikus diabetes mellitus. Jurnal Pangan dan Agroindustri, 2(2): 16-27

Renard, C.B., Krame, F., Johanson, F., Lamharzi, N., Tannock, L.R., von Herrath, M.G., Chait, A. and Bornfeldt, K. (2004). Diabetes and diabetes-associated lipid abnormalities have distinct effect on initiation and progession of atherosclerotic lession. J Clin. Invest, 144 (5) : 659-668.

Stevenson, D.G., Eller, F.J., Wang, L., Jane, J.L., Wang, T. and Inglett, G.E. (2007). Oil and Tocopherol Content and Composition of Pumpkin Seed Oil in 12 Cultivars. J Agric Food Chem, 55 (10) : 4005-4013.

Szkudelski T. (2001). The Mechanism of Alloxan and Streptozotocin Action in B Cells of the Rat Pancreas. Physiological Research, 50(6): 537-546.

Sharma, A., Sharma, K.A., Chand, T., Khardiya, M. and Yadav, C.K. (2013). Antidiabetic and Antihyperlipidemic Activity of Cucurbita maxima Duchense (Pumpkin) Seeds on Streptozotocin Induced Diabetic Rats. Journal of Pharmacognosy and Phytochemistry, 1(6): 108-116.

Setiawan, R. (2010). Pengaruh pemberian ekstrak kelopak bunga rosela (Hibiscus sabdariffa L) terhadap penurunan kadar gula darah tikus putih (Rattus norvegicus) yang diinduksi aloksan. Skripsi, Fakultas Kedokteran. Universitas Sebelas Maret. Surakarta. 
Suwanto. (2015). Potential of Local Food Pumpkin (Cucurbita moschata Duch) as Diversification of Rice to Food Security. The Proceeding of International Joint Conference, 15-16 November 2015, Kediri, Indonesia. Hal. 633-637.

Sari, L.O.R.K. (2006). Pemanfaatan obat tradisional dengan pertimbangan manfaat dan keamanannya. Pharmaceutical Sciences and Research, 3(1): 1-7.

Teugwa, C.M., Boudjeko, T., Tchinda, B.T., Mejiato, P.C. and Zofou, D. (2013). Antihyperglycaemic globulins from selected Cucurbitaceae seeds used as antidiabetic medicinal plants in Africa. BMC Complementary and Alternative Medicine, 3 (63) : 1-8.

Togubua, S., Momuata, I.L., Paendong, E.J. dan Salmaa, N. (2013). Aktivitas Antihiperglikemik dari Ekstrak Etanol dan Heksana Tumbuhan Suruhan (Peperomia pellucida Kunth) Pada Tikus Wistar (Rattus novergicus L.) yang Hiperglikemik. Jurnal Mipa Unsrat Online, 2 (2) : 109-114.

Wahyuni, R.R. (2015). Pengaruh Hipoglikemik Ekstrak Protein Kecipir (Psophocarpus tetragonolobus) Pada Tikus Diabetik Induksi Alloksan. Jurnal Ilmiah Teknosains, 1 (1) : $1-6$.

Wisaniyasa, N.W., Marsono, Y. dan Noor, Z. (2001). Pengaruh Diet Ekstrak Protein Kedelai Terhadap Glukosa Serum Pada Tikus Diabetik Induksi Alloxan. Agritec, 22 (1) : 22-25.

Yadav, N., Morris, G., Harding, S.E., Ang, S. and Adams, G.G. (2009). Various Non-Injectable Delivery Systems for the Treatment of Diabetes Mellitus. Endocrine, Metabolic \& Immune Disorders - Drug Targets, 9 (1) : 1-13. 